\title{
THE PROCESS OF IMPLEMENTING COMPETITIVE INTELLIGENCE IN A COMPANY
}

\author{
František Bartes
}

Received: February 28, 2013

\begin{abstract}
BARTES FRANTIŠEK: The process of implementing Competitive Intelligence in a company. Acta Universitatis Agriculturae et Silviculturae Mendelianae Brunensis, 2013, LXI, No. 4, pp. 861-866

It is a common occurrence in business practice that the management of a company, in an effort to jump-start the function of the Competitive Intelligence unit, makes a number of mistakes and errors. Yet it is not difficult to avoid these missteps and achieve the desired level of Competitive Intelligence activities in a purposeful and effective manner. The author believes that a resolution of this problem lies in his concept of Competitive Intelligence viewed as a system application discipline (like value analysis or value engineering), which is why he approaches the problem of actual implementation of Competitive Intelligence in a company by referring to standards ČSN EN 12973 and ČSN EN 1325-2. The author then proposes his own procedure for implementing Competitive Intelligence in a company. He first describes the various ways of securing the Competitive Intelligence services. Depending on the manner of securing these services, it is necessary to choose the actual method of bringing Competitive Intelligence into the company. The author goes on to lists the essentials that every program of Competitive Intelligence implementation should have. The process of Competitive Intelligence implementation unfolds in three stages, those being: 1. Managerial preparation for the introduction of Competitive Intelligence. 2. Personnel-oriented and professional preparation for applying Competitive Intelligence. 3. Organizational preparation for the implementation and practice of Competitive Intelligence. In Discussion, the author points out the most common mistakes he encountered in practice when implementing the Competitive Intelligence function.
\end{abstract}

competitive intelligence, implementation process, forms of implementation

In a period of crisis, the senior management of every company must seek new ways of surviving, and hopefully prospering, in the challenging business environment. The basis for improving any business is innovation. In order for an innovation to be well chosen and correctly timed, the senior management of the firm must have "the right information at the right time". It happens very often though that the company's existing informational system is unable to identify the information readily available on the market because it does not have a clue how important it is, or is unaware that such an information exists. In many cases we find that the company's top management does not know what information it needs for making decisions, which means that it does not even know what information to request from the system to have some factual basis for these decisions. A survey of domestic firms conducted by Bartes (2001) in the period
1994-2000 (a sample of approximately 130 firms) suggests that the top management of our companies in the majority of cases (about 67\%) does not ask for strategic information about the competing firms as a way to develop an offensive posture in the company's competitive struggle.

In that case, according to Erickson, Rothberg (2005), it is appropriate to ask the following questions, which will reveal how your business secures its access to competitive capital, which is defined as a potential sum of knowledge about the competition that the company is capable of obtaining through legal channels. Those questions are:

1. Do you have all the information you need for your strategic decision making?

2. Do you know where to find the information you need for your decisions? 
3. Do you know what to do with the information you may find?

If at least one of the questions does not have a satisfactory answer, it is time to start forming a Competitive Intelligence unit in our company.

Foreign literature describes the process of implementing Competitive Intelligence activities in divergent terms. From a survey of the available literature touching upon such implementations in the corporate world, it appears that there is no conventional, much less standardized, methodology, aside from an outline of some fundamental organizational activities mentioned in every textbook on management. This is evident in the following publications: (Fuld, 1995), (Kahaner, 1997), (Liebowitz, 2006), (Hall, Bensoussan, 2007), and especially (Carr, 2003), who describes the working methods of 15 foremost experts on Competitive Intelligence in the USA.

In this publication, well-known experts give diverse accounts of integrating Competitive Intelligence into a corporate structure. These descriptions represent different approaches, in many cases merely routines followed by a certain CI expert who found them to be useful.

This article intends to propose an effective procedure how to implement the services of a Competitive Intelligence unit into corporate practice.

\section{METHODS}

The methods employed in writing this article were: analysis, synthesis, induction, deduction, and comparison. Resolution of the problem is based on the standards ČSN EN 12973 "Value management" and ČSN EN 1325-2 "Vocabulary of value management, value analysis and function analysis, Part 1 - Value analysis and function analysis." The various ways of securing Competitive Intelligence service in a company are outlined first, followed by a proposal of an implementation model for Competitive Intelligence in a company.

\section{Point of departure}

The perception of Competitive Intelligence in foreign literature varies a great deal. Some definitions of this term are quoted below.

Competitive Intelligence, according to The Society of Competitive Intelligence Professionals (SCIP) is "a systematic and ethical program for collection, analysis and use of external information which may impact the company plans, decisions, and management" (SCIP, 2010).

A truly successful and credible use of Competitive Intelligence in business practice requires to keep in mind that this activity works on the same principle as intelligence services, which are essential to support decisions at the government level, but it is different in the sense that Competitive Intelligence uses only legal sources of information and legal methods in its work. This understanding of the very substance of Competitive Intelligence is what differentiates us from the majority of authors, whose concept of Competitive Intelligence often verges on some sort of "external" form of Business Intelligence combined with a strategic analysis.

Liebowitz (2006) states that the research of the organization SIS International Research (Klein) conducted among the Competitive Intelligence professionals in 2004 demonstrated that the item with the highest added value in Competitive Intelligence is strategic planning.

The foregoing implies that corporate Competitive Intelligence, when understood in theory and applied in practice, "makes predictions for the future".

It is in this, and only this, sense (1) that Competitive Intelligence is significant for a company.

This means that the information received has to be enhanced, in a process called intelligence analysis (Bartes, 2011), with an added value that transforms it into real intelligence - i.e. the already mentioned prognosis that forms the basis for strategic decisions of the company's top management.

In general, Competitive Intelligence is subject to the following requirements:

a) to recognize, in a timely manner, the company's key problems arising from the business environment,

b) to secure possible solutions to these problems from an intelligence standpoint.

For our concept of Competitive Intelligence, we shall first define the scope (2) of its activities:

Competitive Intelligence is a methodical complex, in this application intended for commercial purposes, that serves as a tool of corporate management in the preparation of materials instrumental in making strategic decisions.

It can apply to innovations, investments, future company direction, developments in markets, sectors, customers, competition, business partners etc., see Kocmanová, Dočekalová (2011).

The preceding remarks now permit to define our understanding of the Competitive Intelligence concept (Bartes, 2010):

Competitive Intelligence is a systematic, creative, and ethical application of intelligence-gathering methodology and other key methods, which utilizes teamwork to...

- collect and identify symptoms, data, and/or information sources

- analyze the symptoms, data, and collected information, complete these materials, evaluate their significance, and organize them into evidence of some developments

- from the available information, hypothesize plausible changes (predictions of future states) and evaluate their benefit in terms of the associated evidence and costs to ascertain the effectiveness of these changes,

- prepare intelligence reports to support the decision making process of corporate management. 
It should be noted in this connection that, for a decision maker, information becomes an advantage (weapon) only when he is able to turn it into intelligence, in other words to recognize its importance as an opportunity to gain, or create, a competitive advantage for his business.

\section{RESULTS}

Introducing Competitive Intelligence into a business operation has its pitfalls. If this undertaking is not to become a one-time venture but a systematic activity, it is necessary to create appropriate human, organizational, and physical conditions. For example, an important factor is the size of the company and the resources it can allocate to this endeavor. The company's economic strength therefore translates into more options in introducing or running Competitive Intelligence as a way of charting the future development. It is a fairly complicated matter that requires to gather data and information, perform intelligence analyses, and propose a new strategies for business entities. Team work is obviously preferred. The devised strategy has to be both realistic and feasible, so the team should unite experts from different fields germane to the given type of business. The team should be led by an expert - a methodical individual familiar with the Competitive Intelligence working plan as well as other measures used in this type of work.

The work on a proposal how to introduce Competitive Intelligence in a company should start by clarifying one basic question:

\section{Who will be the recipient of the outputs from this Competitive Intelligence system?}

The answer to this question will determine the kind of intelligence (strategic, operational) the Competitive Intelligence unit will pursue. We further need to find out WHAT it is that the recipients of the Competitive Intelligence reports actually need. This, in essence, is the issue of Key Intelligence Topics (3) - KIT, see Herring (2006), and Prescott, Miller (2001). Well defined intelligence needs are the starting point for a professional preparation and implementation of the entire intelligence process, or the full cycle of Competitive Intelligence. This means that the quality (precision, accuracy) with which the intelligence needs of the company's top management are defined sets the standard for the contribution and importance that Competitive Intelligence will have in that company.

With the intelligence needs of the company's top management defined, we can begin to propose a model for the implementation of Competitive Intelligence in a company.

The Competitive Intelligence function can be secured in the following manner:

1. By the company management as a team (suitable for smaller or small businesses), possibly in cooperation with an expert from some external organization.

2. By a professional Competitive Intelligence unit of the firm, instituted specifically for this purpose, in cooperation with both company personnel and external organizations.

3. By a company-contracted external organization (e.g. a college doing a research project, and the like).

4. By an appointed team of company employees under an expert guidance of a Competitive Intelligence specialist from an external organization, or a trained employee of the company's Competitive Intelligence (CI Coordinator), or by a member of a professional Competitive Intelligence unit.

Depending on the preferred approach to secure the Competitive Intelligence function, it is necessary to define how it will be implemented. However, before the management decides on the form of CI implementation, it should hold an introductory seminar with a discussion about the existing method of company management, especially in regards to critical situations that foreshadow every change in strategy.

The management should understand that even being a supplier to another company is not necessarily forever, and that there has to be a plan in case that the relatively comfortable contract is lost. There should also be a corporate directive how to do this activity, which should not contain anything considered secret.

\section{Forms of introducing Competitive Intelligence}

The introduction of all modern methods from the category of "system application disciplines" into corporate practice follows a similar pattern. In this case we can use the experience from implementing, for example, a methodical complex called "value management" which, in the Czech Republic, is regulated by European standards.

These standards are ČSN EN 12973 "Value management", and ČSN EN 1325-2 "Vocabulary of value management, value analysis and function analysis - Part 1. Value analysis and function analysis", which contain a set of activities that allow a company to conduct the development, implementation, and maintenance of a methodical process in an on-going manner.

The responsibility for CI implementation should be entrusted to a single individual. The program of CI introduction in an organization, per Dostál, Loubal, Bartes (2009), should include:

- Integration and preparation of a methodical procedure inside and outside the organization.

- Setting targets or indicators as needed to evaluate the results of actions taken.

- Projects or studies conducted within the CI arena.

- Procedures for management-imposed measures in implementing the results of projects or studies. 
- Provision for a feedback mechanism regarding the CI results.

- Outlining the forms of possible cooperation with external organizations.

The actual process of CI introduction of should be, like the other system application disciplines, divided into three phases, see Dostál, Loubal, Bartes (2009):

a) Managerial preparation for the introduction of CI.

b) Personnel-oriented and professional preparation for the application of CI.

c) Organizational preparation for the implementation and practice of CI.

\section{a) Managerial preparation}

This phase of the process involves the following steps:

1. The management becomes familiar with CI.

2. Decision to implement CI in the company.

3. Forms of implementing and operating defined.

4. Person responsible for the implementation and function appointed.

\section{b) Personnel-oriented and professional preparation}

This phase may involve the following steps:

1. Review of personal qualifications to work in a CI team.

2. Selection of qualified people for this work, within the company or via an external search.

3. Training of the selected staff in CI methodology and related activities.

\section{c) Organizational preparation for the implementation and practice of CI}

It should cover the following items:

1. Task assignment procedure.

2. Appointment of CI Team leader.

3. Task termination procedure.

4. Workers' classification system.

5. CI performance reward system.

When preparing to implement Competitive Intelligence, one should start with a basic insight proved to be true many times over in business practice (Fuld, 1995), namely the fact that the foundation of a successful information system is the corporate culture.

This means that the system is based primarily on people. For a system of Competitive Intelligence to be truly functional (beneficial to the company), it must be, per (Fuld, 1995), based on the following three fundamental principles:

1. Stability.

2. Long-term perspective.

3. Involvement.

The employees of every business represent a wealth of knowledge and valuable information about the competition. The task of securing (capturing) the necessary data or information calls for building a wide-spread corporate information network so that the relevant data could be gathered within the company (this is normally the task of Business Intelligence). Creating a socalled "intelligence map of the company" helps accomplish that task. In corporate practice, the task is handled with the assistance of an intelligence audit.

Conducting an intelligence audit:

a) Classification of workers by their expertise: technology, design, economy, trade, human resources, etc.

b) Preparation of diagrams (maps) of knowledge for each specialty, department, etc.

c) Definition of a formal way to store data, information, knowledge.

d) Definition of a differentiated access to stored information for individual users.

An essential part of the Competitive Intelligence integration in a company is its protection, encompassing the legal, technical, and organizational aspects as well as personnel, security and counterintelligence.

\section{DISCUSSION}

From the practical experience of implementing the Competitive Intelligence service in businesses, it can be said that the results, or benefits, of this work to the company depend, to a large extent, on the caliber of its top executives or, more precisely, what type of managers they are. In corporate practice, we often meet the managers who want to know "everything" (sic) about a given problem (but in fact are not sure WHAT they want). It is also possible to encounter managers who are woefully unprepared to make use of the materials proffered by Competitive Intelligence. The situation is much better with those managers who understand the importance of the outputs coming out of Competitive Intelligence units and try to articulate their informational needs (for example by defining the KIT) in a mutual interaction with the leaders of the Competitive Intelligence unit.

The most frequent mistakes made when companies introduce Competitive Intelligence

When implementing a Competitive Intelligence system in practice, one should be aware of some pitfalls and errors that the management and the employees tend to make. The most common ones, sometimes contradictory, are the following:

1. The senior and/or the middle management of the firm distrusts the CI outputs.

2. Top company management harbors an unrealistic perception grounded in the belief that this unit will handily resolve all the company problems (like a superman, the company's one and only master of all trades). 
3. Minimal effort of the CI staff to work with the primary data sources.

4. Most of the CI workers' time is spent attending to operational tasks instead of producing materials for strategic decisions of the company's top management.

5. Inability to make the most of all the advantages and possibilities that CI offers (utilization of its entire intelligence potential).

6. In many cases, the CI unit output (final report, if it is prepared) represents a synthesis rather than analysis. This signifies that the result extracted by intelligence analysis, i.e. the precious added value, must be created (typically by a fairly sophisticated proces) and not only compiled from the collected data.

7. The final report often does not address the possible upcoming moves of the competition (in a hypothetical form), and the assessment of their potential impact on business developments as it pertains to business sectors, competitors, suppliers, customers, and our business as well. The report should also propose our possible responses to the competitors' moves.

8. A premature (and therefore usually inappropriate) purchase of an expensive intelligence software.

9. Uncritical adoption of modern "western" methods without sufficient knowledge and/or assurance of applicability.
10. Top management fails to create favorable conditions for a successful deployment of CI activities (education, training, provision of equipment, instruments, resources, etc.)

\section{CONCLUSION}

The above-described model of implementing the function of a Competitive Intelligence unit in corporate practice was followed in four companies. It took, on average, three months to implement the model. The results, in the form of documents generated to support the strategic decisions of the company's top management, began to show in the next five to six months after the CI had been introduced.

During this time, it was already possible to collect a large amount of information about the competitive activities gleaned from the company sphere of interest, and subject it to an intelligence analysis, see Bartes (2011). Thereafter, it was possible to generate the first intelligence reports that served as a basis for corporate strategic decisions, thereby reducing the risk inherent in making those decisions, see Martinovičová et al. (2010).

Competitive Intelligence plays an important role in the corporate management's preparation to make strategic decisions that would create new conditions to ensure the company's future prosperity in the unforgiving business environment. It is considered to be one of the most powerful perspective weapons in management's hands.

\section{SUMMARY}

It happens very often in business practice that the management, in an effort to quickly secure the services of a Competitive Intelligence unit, is prone to make a number of mistakes and errors. These missteps are conducive to a dramatic decline in the quality of results produced by that unit. The failure to meet the set objectives usually leads to a dissolution of this CI unit. Yet these incidents could be prevented and the desired level of Competitive Intelligence activities achieved in an effective, goal-oriented manner. The author considers his concept of Competitive Intelligence as a system application discipline (like value analysis or value engineering) to be the starting point in addressing the problem, which is why he works with his own definition of Competitive Intelligence.

In dealing with the challenge of a practical implementation of Competitive Intelligence in a company, the author relies on the standards ČSN EN 12973 and ČSN EN 1325-2. He then presents his own proposal for the process of implementing Competitive Intelligence in a company. It starts with a list of the ways how a company can secure the Competitive Intelligence services. After deciding on the method of securing this function, it is necessary to choose the method of actually implementing Competitive Intelligence in the company. The author then proceeds to provide a list of essentials that every program of Competitive Intelligence implementation should have.

The actual process of implementing a Competitive Intelligence program consists of three phases, which are: 1. Managerial preparation for the introduction of Competitive Intelligence. 2. Personneloriented and professional training for the application of Competitive Intelligence. 3. Organizational preparation of the implementation and practicing of Competitive Intelligence.

The author asserts that a particularly risky part of the process of bringing Competitive Intelligence services to a company is the attitude of the corporate top management toward the Competitive Intelligence activities, especially toward the outputs from these activities and their value in making strategic decisions. In Discussion, the author points to common mistakes in implementing Competitive Intelligence as observed in his own experience.

The model of Competitive Intelligence implementation in corporate practice mentioned in the article has already been followed in four companies. The implementation took an average period of four 
months. The results in terms of generating documents for strategic decisions of the company's top management began to show in the period of the next five to six months.

\section{Footnotes:}

1. We believe that particularly this ability of the company is one of those that differentiate the successful enterprise from the unsuccessful one.

2. The prerequisites of Competitive Intelligence as a separate specialty were stated in publication (Bartes, 2010).

3. A successful activity of the Competitive Intelligence Unit in corporate practice requires a systemic control of the process to determine the intelligence that the company management needs. This process has to be based on a bilateral communication between the company management and the Competitive Intelligence Unit leadership for the purpose of defining the real intelligence needs.

Acknowledgement

This paper is the output of the project "Microeconomic and macroeconomic principles and their effect on the behaviour of households and firms." The project is funded by the Internal Grant Agency of Brno University of Technology and its registration number is FP-S-13-2052."

\section{REFERENCES}

BARTES, F., 2001: Konkurenční boj firmy. In: Možné trendy vývoje strojirenských podnikü se zŕetelem na jihomoravský region II. Výzkumná zpráva institucionálního výzkumného úkolu CEZ: J22/98: 265 100017. Brno: VUT v Brně, 362 s. ISBN 80-214-2102-9.

BARTES, F., 2010: Competitive intelligence - tool obtaining specific basic for strategic decision making TOP management firm. Acta univ. agric. et silvic. Mendel. Brun., 58, 6: 43-50. ISSN 1211-8516.

BARTES, F., 2011: Intelligence analysis - the royal discipline of Competitive Intelligence. Acta univ. agric. et silvic. Mendel. Brun., 59, 7: 39-56. ISSN 12118516.

CARR, M. M., 2003: Super Searchers on Competitive Intelligence. New Jersy: Reva Basch, 331 p. ISBN 0-910965-64-1.

DOSTÁL, V., LOUBAL, J. a BARTES, F., 2009: Hodnotové inženýrství. Cesta $k$ dosažení komerčně úspěšného výrobku. Ostrava: KEY Publishing, 375 s. ISBN 978-80-7418-003-3.

ERICKSON, S. G. and ROTHBERG, N. H., 2005: From Knowledge to Intelligence. Creating Competitive Advantage in the Next Economy. Oxford: Elsevier Butterworth-Heinemann, 365 p. ISBN 0-75067762-7.

FULD, L. M., 1995: The New Competitor Intelligence. New York: John Wiley \& Sons, 482 p. ISBN 0-47158509-2.

HALL, CH. and BENSOUSSAN, B., 2007: Staying Ahead of the Competition. New Jersy: World Scientific, 150 p. ISBN 978-981-277-906-9.
HERRING, J., 2006: KITs Revisited: Their Use and Problems. Competitive Intelligence Magazine, 9, 5: 4-14. ISSN 1521-5881.

KAHANER, L., 1997: Competitive Intelligence. New York: Simon \& Schuster, 304 p. ISBN 978-0-68484404-6.

KOCMANOVÁ, A. and DOČEKALOVÁ, M., 2011: Environmental, Social, and Economic Performance and Sustainability in SMEs. In: Relation to Measurement of Company Performance. Proceedings of the 10th international conference Liberec economic forum. Liberec: Technical University of Liberec, Faculty of Economics, 242-251. ISBN 978-80-7372-755-0.

LIEBOWITZ, J., 2006: Strategic Intelligence. New York: Taylor \& Francis Group, 248 p. ISBN 0-8493-98681 .

MARTINOVIČOVÁ, D., BERANOVÁ, M., POLÁK, J. a DRDLA, M., 2010: Teoretické aspekty kategorizace rizik. Acta univ. agric. et silvic. Mendel. Brun., 57, 3: 131-136. ISSN 1211-8516.

PRESCOTT, J. E. and MILLER, S. H., 2001: Proven Strategies in Competitive Intelligence: Lessons from the Trenches. New York: John Wiley and Sons, 288 p. ISBN 978-04-71401-78-0.

SCIP, 2010: About SCIP. [online]. Alexandria, Virginia USA. [cit. 2010-08-12]. Dostupné z: <http://www.scip.org/content.cfm?itemnumber $=2214 \&$ navItemNumber $=492>$.

ČSN EN 1325-1, 1997: Slovník hodnotového managementu, hodnotové analýzy a funkčni analýzy část 1. Hodnotová analýza a funkéní analýza. Praha: Český normalizační institut.

ČSN EN 12 973, 2000: Hodnotový management. Praha: Český normalizační institut. 